\title{
Factors that influence French consumer satisfaction in the preference for Chilean avocados (Persea Americana Mill.)
}

\author{
Ricardo Cabana Villca ${ }^{1}$, María I. Ortega Marín ${ }^{1}$, Alondra A. Gutiérrez \\ Rojas $^{1}$, Mauricio I. Aguilera Zambra ${ }^{1}$, and Andrés F. Chiang Guzmán ${ }^{2}$ \\ ${ }^{1}$ Universidad de La Serena, Facultad de Ingeniería, Departamento de Ingeniería Industrial. Casilla 554, La \\ Serena, Chile. \\ ${ }^{2}$ Universidad La República, Dirección de Postgrado e Investigación. Sta. Rosa 697, Coquimbo, Chile.
}

\begin{abstract}
R. Cabana Villca, M.I. Ortega Marín, A.A. Gutiérrez Rojas, M.I. Aguilera Zambra, and A.F. Chiang Guzmán. 2021. Factors that influence French consumer satisfaction in the preference for Chilean avocados (Persea Americana Mill.). Int. J. Agric. Nat. Resour. 45-56. Most avocados consumed in France come from Peru or Chile. French suppliers vary based on the season; however, Chile is the main supplier of avocados during the winter season. The aim of this study is to analyze the key variables that influence French consumer satisfaction in the preference for Chilean avocados. This is substantiated using an exploratory multivariate analysis, which was performed on a causal model comprised of endogenous constructs: perceived extrinsic and intrinsic quality, perceived risk and perceived value. The sample consists of 346 French consumers of Chilean avocados in supermarkets of the Auvergne-Rhône-Alpes region. The main results show that the risk perceived by French consumers can only be related to the perceived extrinsic quality of the product. On the other hand, both perceived intrinsic and extrinsic quality are directly related to perceived value. Finally, it is concluded that French consumer satisfaction in the preference for Chilean avocados can be explained by the variables perceived intrinsic quality, perceived extrinsic quality and perceived value.
\end{abstract}

Keywords: Avocado, perceived quality, perceived risk, perceived value, satisfaction, structural equation modeling.

\section{Introduction}

The avocado market is experiencing strong growth in its consumption in most European countries, with 1,127,781 tons imported in 2019. France is a highly appreciated market by avocado exporters, with more than 164,970 tons imported per year

Received Aug 16, 2020. Accepted Jun 08, 2021

Corresponding author: rcabana@userena.cl
(ITC, 2020a), and projections are expecting that to double. France, not being an avocado producer, is fully dependent on imports. Most avocados consumed in France come mainly from Spain, Israel and Latin America, mainly Peru and Chile. Recently, avocados have begun to arrive from Colombia, Argentina and Morocco, but their visibility is still low. French suppliers vary based on the season; Chile is the main supplier during the winter season (ProChile, 2018). 
Chile is one of the main exporters of this superfood. World exports in 2019 were 156,973 tons, 12,500 more than in 2018, of which 10,709 tons were imported to France (ITC, 2020b).

The French consumer stands out as being impulsive, a frequent buyer and trying new and innovative products. Avocado is part of the French people's eating habits, commonly being consumed in salads, sushi, puréed, as an ingredient in sandwiches, frozen, in smoothies or simply naturally. Its consumption is considered heterogeneous in French territory because it is consumed more in the city than in the country, especially in Paris (ProChile, 2018).

The perception of quality is gaining importance for European consumers, and maintaining consumer confidence in food authenticity and the integrity of the food supply chain overall will potentially circumvent the negative economic and societal effects associated with consumer concerns about the associated safety and integrity of food (Kendall et al., 2019).

From this perspective, European countries have increased their levels of perception of food safety, transforming it into an issue of interest and concern for both European citizens and public authorities for several decades (Eygue et al., 2020).

Chile, like the rest of the avocado and other food exporting countries, must deliver products meeting high standards, since the food perception of consumers can be affected by several factors, such as health properties, minimal processing and food additives (Marti et al., 2021).

Food security has had an impact on the so-called "health-conscious consumer" who is characterized by seeking food with a high perception of nutritional value (Gazant et al., 2016).

The perceived value of foods and the perception of risk affect consumer satisfaction, and it is well established for consumers that the highest levels of satisfaction are associated with healthy eating habits, such as a higher frequency of consumption of fruits and vegetables and a lower frequency of meals at fast-food stores (Schnettler, et al., 2020)

Therefore, the main aim of the study is to determine French consumer satisfaction in the preference for Chilean avocados, incorporating variables such as perceived risk, perceived quality and value.

\section{Theoretical framework and hypothesis}

At present, there are four main approaches to explain perceived quality: information economics, means-end chain, integrated and the multiattribute approach (Ness et al., 2010), with the last one being used in this study. The multiattribute approach envisages quality as a dichotomy between intrinsic and extrinsic signals (Chiang et al., 2018).

Intrinsic signals are characteristics that comprise the physical product and are objectively measured for quality. These qualities can be evaluated prior to consumption or can be experienced through consumption based on their sensory properties. On the other hand, extrinsic attributes are related to the product but are not part of it physically. These external signals generate expectations in the consumer regarding food products and affect their choices, sensory perception and hedonic taste. Consumers' perception of quality is particularly important in the act of purchasing and consuming food products because it supposes the benefit the consumer perceives (Shaharudin et al., 2010).

Han \& Hyun (2017) hold that perceived quality is highly correlated with satisfaction, with the former preceding the latter. Satisfaction is a general perception based on the assessment of customers' experiences with a product. Therefore, high satisfaction can only be achieved if a product can satisfy the customer's needs.

Yu et al. (2017) focused on the relation between perceived quality and perceived value, stating 
that perceived quality is an antecedent with a positive effect on value. Perceived value is an abstract concept with different meanings resulting from the overall assessment by consumers of a product's utility based on the perception of what is received and what is given.

García et al. (2017) provide evidence of a link between value and satisfaction, concepts that have received a great deal of attention in the literature due to their strong and direct relation, being part of the foremost useful constructs to understand the consumer's behavior; and there is a natural affinity, since both concepts arise from evaluative judgments.

Yu et al. (2017) conclude that perceived value has a direct and negative correlation with perceived risk by customers. The risk is the consumer's perception of uncertainty and adverse consequences of participating in an activity. When making a purchase, consumers look not only for immediate benefits but also for the long-term implications of the purchase, such as the damage it can cause. If customers perceive that the high risks exceed the benefits, the perceived value will fall, and therefore, the intent to purchase could be reduced (Yu et al., 2017).

Marakanon \& Panjakajornsak (2017) maintain that perceived quality and perceived risk present direct and negative correlations, since any action taken by a consumer will produce consequences that they cannot anticipate with certainty, and some of these will likely be disagreeable. This is important because lower perceived risks yield a higher perceived quality and, consequently, a greater willingness to pay.

Table 1 shows a summary of each definition of perception.

The following hypotheses were tested:

H1: Perceived risk significantly and negatively influences perceived intrinsic quality.

H2: Perceived risk significantly and negatively influences perceived extrinsic quality.

H3: Perceived risk significantly and negatively influences perceived value.

H4: Perceived extrinsic quality significantly and positively influences perceived value.

H5: Perceived intrinsic quality significantly and positively influences perceived value.

H6: Perceived value significantly and positively influences satisfaction.

H7: Perceived intrinsic quality significantly and positively influences satisfaction.

H8: Perceived extrinsic quality significantly and positively influences satisfaction.

Table 1. Definition of perception components

\begin{tabular}{l} 
Perceived Component \\
$\begin{array}{l}\text { Those characteristics that comprise the physical product and measure quality } \\
\text { objectively }\end{array}$ \\
$\begin{array}{c}\text { These characteristics that comprise the physical product and measure quality } \\
\text { objectively }\end{array}$ \\
$\begin{array}{c}\text { Perceived value } \\
\text { Overall assessment by consumers of a product's utility based on the perception of what } \\
\text { is received and what is given }\end{array}$ \\
$\begin{array}{c}\text { Consumer's perception of uncertainty and adverse consequences of participating in an } \\
\text { activity. }\end{array}$ \\
\hline
\end{tabular}


These hypotheses comprise the proposed causal model to measure French consumer satisfaction in the preference for Chilean avocados (Figure 1).

\section{Materials and methods}

\section{Sample and questionnaire}

A survey was applied to a nonprobability convenience sample (Chiang et al., 2018). The sample surveyed 346 people of French nationality. The field work was done in person by interviewers in France using a survey designed in Spanish in Chile and then translated into French. In addition, to improve the survey-taking process, a user manual was created in French, which was meant to instruct and guide the interviewers, reducing the likelihood of making mistakes in data collection. The evaluation instrument was applied between July and September 2019 in supermarkets in Grenoble, Valence and Romanssur-Isère in the Auvergne-Rhône-Alpes region of France.

The evaluation instrument included questions about perceived extrinsic quality (PEQ), perceived intrinsic quality (PIQ), perceived value $(\mathrm{PV})$, satisfaction (ST) and perceived risk (PR). Data collection was quantitative based on a structured survey of 13 statements on a Likerttype scale (1: not important; 5: very important) for perceived quality, 4 statements for satisfaction (1: strongly disagree; 5 : strongly agree), 4 statements for perceived value (1: very low, 5: very high) and 5 statements on a Likert-type scale for perceived risk (1: strongly disagree; 5: strongly agree).

Measurement of the intrinsic attributes was based on previous studies by Ness et al. (2010) and Chiang et al. (2018). The items used were color, size, flavor and texture. The extrinsic attributes were adapted from the items collected by Chiang et al. (2018). The items used were price, seals of quality, availability in supermarkets, price discount, variety of the fruit, recommendation by the seller, net packing, availability in bulk and Chilean origin. The measurements of perceived risk were based on previous literature on food products and statements adapted from the measurements contained in Yeung et al. (2010). The variables used for this construct were hygiene standards in fruit production, use of artificial pesticides in fruit production, genetic modification in production, hygiene standards in distribution and artificial preservation techniques in the distribution of the product. The indicators of the attributes of perceived value were based on studies by Ness et al. (2010). The items used

Figure 1. Causal model of French consumer satisfaction with Chilean avocados

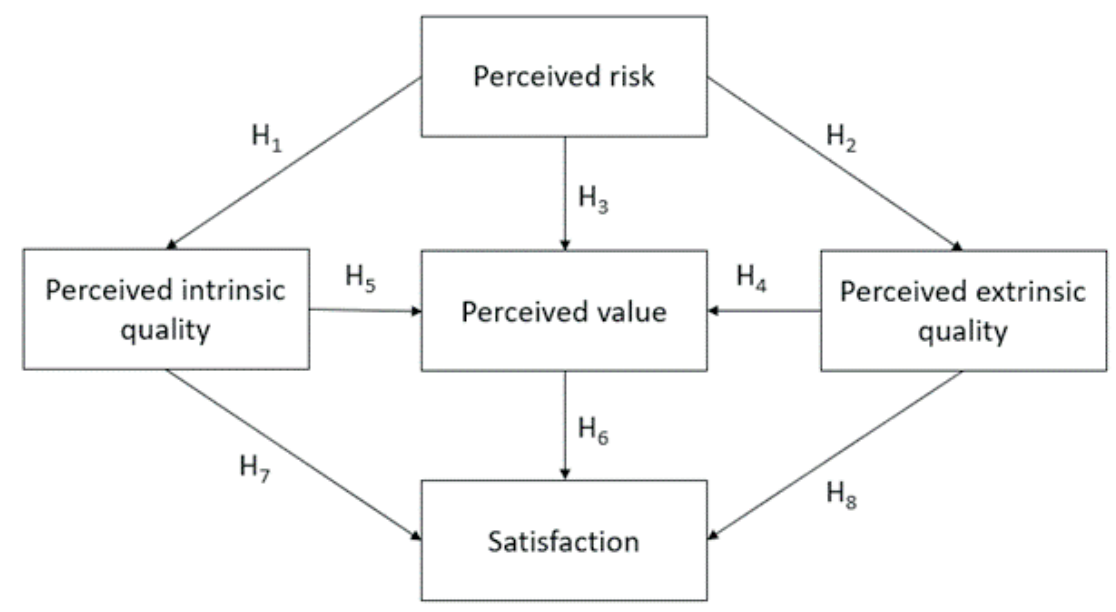


were assessment of the nutritional state of a fresh product, assessment when paying a higher price than usual for a fresh product, assessment of the shelf life of a fresh avocado while maintaining quality, assessment of the economic price of a fresh product and assessment when considering a fresh product to be a good purchase. The indicators of the attributes of satisfaction were based on studies by Espejel \& Fandos (2009) and Chiang et al. (2018). The items used were I am satisfied with the product, the product meets my purchase expectations, I am satisfied with the seller of the product, and I am satisfied with the price I paid for the product.

\section{Individual reliability of the indicators}

The evaluation of the viability of the factorial analysis of each construct employed the KaiserMeyer-Olkin index (KMO), which for each of the factors must be greater than 0.50, and Bartlett's test of sphericity (BTS), which must be significant, i.e., less than 0.05 . To accept a variable as integral to a construct, factor loads with values greater than 0.4 were considered.

\section{Construct reliability and validity}

To evaluate the reliability of a construct, the internal consistency of all indicators that measure the same concept is verified, i.e., the rigor with which the latent variables are being measured is assessed. To perform this evaluation, Cronbach's alpha was used, which must be greater than 0.7 , as well as the composite reliability coefficient (CRC), which takes into account the interrelations of the constructs and has a minimum value of 0.7 .

To analyze the validity of the constructs, the average variance extracted (AVE) was used. The acceptance criterion consists of the AVE of a construct greater than 0.5 , meaning that the construct shares more than half of its variance with its indicators.

\section{Structural equations model}

Once these tests were complete, hypothesis contrast was performed, and the goodness-of-fit of the model was estimated. For this study, three analyses of goodness were used: a) root mean square error of approximation (RMSEA), with its maximum accepted value being less than 0.08 , and b) the comparative fit index (CFI), which must be greater than 0.93 .

\section{Results and discussion}

The sample presents four characteristics: the consumers are mainly women, over 36 years of age, in active work and with a lower-middle purchasing power (Table 2). Plessz et al. (2015) state that women consume more fruits and vegetables because they have better nutritional knowledge and do most of the cooking in European countries. In the same vein, Mertens et al. (2018) report that in France and Europe generally, fruit and vegetable intake has remained at mean levels, being acquired preferentially by women. With respect to the age range of the sample, Plessz et al. (2015) demonstrate the gradual increase in fruit and vegetable intake by French consumers as they age and move from active work to aging and retirement.

On the other hand, the results of the factorial analysis gave a KMO indicator of 0.67 , whereas BTS was less than 0.001, indicating that the correlation matrix is not an identity matrix, which makes it possible to perform a factorial analysis with the data.

With respect to the factor load analysis, the study determined through the individual reliability of the indicators (Table 3) that the observable variables color (ATRI01), size (ATRI02), flavor (ATRI03) and texture (ATRI04) are part of the construct perceived intrinsic quality. Studies such as that by Moreno-Ortega et al. (2019) on avocados associate the size of the fruit harvested in Spain as 
Table 2. Sociodemographic profile of the sample

\begin{tabular}{|c|c|c|c|}
\hline Variable & Item & Frequency & Percentage \\
\hline \multirow[t]{2}{*}{ Gender } & Male & 58 & 16.8 \\
\hline & Female & 288 & 83.2 \\
\hline \multirow[t]{5}{*}{ Age } & Under 18 & 1 & 0.30 \\
\hline & From 18 to 25 & 54 & 15.6 \\
\hline & From 26 to 35 & 64 & 18.5 \\
\hline & From 36 to 50 & 93 & 26.9 \\
\hline & Over 50 & 134 & 38.7 \\
\hline \multirow[t]{4}{*}{ Education level } & Primary & 11 & 3.20 \\
\hline & Secondary & 76 & 22.0 \\
\hline & Technical & 205 & 59.2 \\
\hline & University & 54 & 15.6 \\
\hline \multirow[t]{2}{*}{ Type of work } & Active & 269 & 77.8 \\
\hline & Retired & 77 & 22.2 \\
\hline Average monthly & Less than $€ 1700$ & 165 & 61.3 \\
\hline \multirow[t]{2}{*}{ Income, Active workers } & From $€ 1700$ to $€ 3000$ & 102 & 37.9 \\
\hline & More than $€ 3000$ & 2 & 0.80 \\
\hline Average monthly & Less than $€ 800$ & 31 & 40.2 \\
\hline \multirow[t]{2}{*}{ income, Retirees } & From $€ 800$ to $€ 1200$ & 34 & 44.2 \\
\hline & More than $€ 1200$ & 12 & 15.6 \\
\hline
\end{tabular}

a quality indicator, relating its small size to water scarcity and the lack of adopted irrigation policies and strategies. Similarly, Iglesias et al. (2008), in their study on apples, describe the adequate development of the color at harvest as a serious problem in most southern European countries, where warm summers and droughts do not favor the development of the color of the fruit.

For the construct perceived extrinsic quality, the variables Chilean origin (ATRI05), availability in supermarkets (ATRI07), price discount (ATRI08), availability in bulk (ATRI12) and price (ATRI13) were accepted. Mora et al. (2011), in their studies on peaches in Spain, and Hurgobin et al. (2020), in their studies on apples in France, concluded that the price variable is one of the most important within the construct of perceived extrinsic quality. On the other hand, the variable origin can influence consumers' fresh food preferences, as Insch $\&$ Cuthbert (2018) have demonstrated. However, European consumers usually prefer products of local origin over imported ones, which is a clear entry barrier for products, as demonstrated by Hurgobin et al. (2020) in their studies on apples in France.
The indicators I am satisfied with the product (ATRI14), the product meets my purchase expectations (ATRI15) and I am satisfied with the price I paid for the product (ATRI17) were part of the construct satisfaction, confirming the studies conducted on foods in Spain by Espejel \& Fandos (2009), who reported results similar to those found in this study. In a similar vein, Lombart \& Louis (2014) showed that price is directly linked to consumer satisfaction in retail markets in France.

The construct perceived value was represented statistically by the indicators assessment of the nutritional state of a fresh product (ATRI18), assessment when paying a higher price than usual for a fresh product (ATRI19) and assessment of the economic price of a fresh product (ATRI21). The French National Food Council has conducted studies that link nutritional value, price and food type. Their studies revealed that those products with a lower price and discounts provide the consumer with less nutritional information (Perrin et al., 2017), which are key factors in determining the perceived value according to the studies by Ness et al. (2010). 
Table 3. Reliability of the indicators

\begin{tabular}{|c|c|c|c|}
\hline Proposed construct & Attribute & Code & Critical ratio \\
\hline Perceived intrinsic & Color & ATRI01 & $\mathrm{Nd}$ \\
\hline \multirow[t]{3}{*}{ quality (PIQ) } & Size & ATRI02 & $11.693 * * *$ \\
\hline & Flavor & ATRI03 & $12.109^{* * *}$ \\
\hline & Texture & ATRI04 & $11.424 * * *$ \\
\hline \multirow{9}{*}{$\begin{array}{l}\text { Perceived extrinsic } \\
\text { quality (PEQ) }\end{array}$} & Chilean origin & ATRI05 & $\mathrm{Nd}$ \\
\hline & Seals of quality & ATRI06 & $\mathrm{Ni}$ \\
\hline & Availability in supermarkets & ATRI07 & $11.979 * * *$ \\
\hline & Price discount & ATRI08 & $11.969 * * *$ \\
\hline & Variety of the fruit & ATRI09 & $\mathrm{Ni}$ \\
\hline & Recommendation by the seller & ATRI10 & $\mathrm{Ni}$ \\
\hline & Net packing & ATRI11 & $\mathrm{Ni}$ \\
\hline & Availability in bulk & ATRI12 & $11.420^{* * *}$ \\
\hline & Price & ATRI13 & $11.596^{* * *}$ \\
\hline \multirow[t]{4}{*}{ Satisfaction (ST) } & I am satisfied with the product & ATRI14 & $\mathrm{Nd}$ \\
\hline & The product meets my purchase expectations & ATRI15 & $11.805^{* * *}$ \\
\hline & I am satisfied with the seller of the product & ATRI16 & $\mathrm{Ni}$ \\
\hline & I am satisfied with the price I paid for the product & ATRI17 & $11.601^{* * *}$ \\
\hline \multirow[t]{6}{*}{ Perceived value (PV) } & Assessment of the nutritional state of a fresh product & ATRI18 & $\mathrm{Nd}$ \\
\hline & $\begin{array}{l}\text { Assessment when paying a higher price than usual for a fresh } \\
\text { product }\end{array}$ & ATRI19 & $9.568 * * *$ \\
\hline & $\begin{array}{l}\text { Assessment of the shelf life of a fresh avocado while main- } \\
\text { taining quality }\end{array}$ & ATRI20 & $\mathrm{Ni}$ \\
\hline & Assessment of the economic price of a fresh product & ATRI21 & $9.950 * * *$ \\
\hline & Assessment when considering a fresh & ATRI22 & $\mathrm{Ni}$ \\
\hline & product to be a good purchase & & \\
\hline Perceived risk & Hygiene standards in fruit production & ATRI23 & $\mathrm{Nd}$ \\
\hline \multirow[t]{4}{*}{ (PR) } & Use of artificial pesticides in production & ATRI24 & $19.414 * * *$ \\
\hline & Genetic modification in production & ATRI25 & $\mathrm{Ni}$ \\
\hline & Hygiene standards in distribution & ATRI26 & $\mathrm{Ni}$ \\
\hline & $\begin{array}{l}\text { Artificial preservation techniques in } \\
\text { distribution of the product }\end{array}$ & ATRI27 & $11.521 * * *$ \\
\hline
\end{tabular}

***Significantly lower than 0.05 . Nd: not determined because this regression coefficient was adjusted to 1 to identify the model. $\mathrm{Ni}$ : not incorporated into the model as a variable because it is insignificant.

Finally, the construct perceived risk comprises the following indicators: hygiene standards in production (ATRI23), use of artificial pesticides in fruit production (ATRI24) and artificial preservation techniques in the distribution of the product (ATRI27). Studies on fruits and vegetables by Baselice et al. (2017) conclude that consumers show strong preferences for fresh and recently cut products and the use of natural preservatives rather than the use of inert gases, which is why it is expected that these variables negatively influence perceived quality in the consumer (Figure 2).

The reliability analyses met the standards recommended by the literature (Table 4). For Cronbach's alpha, the values were greater than 0.7 for the five constructs, which is why they are reliable to measure individually. At the same 
Figure 2. Structural equations model that explains French consumer satisfaction with avocados

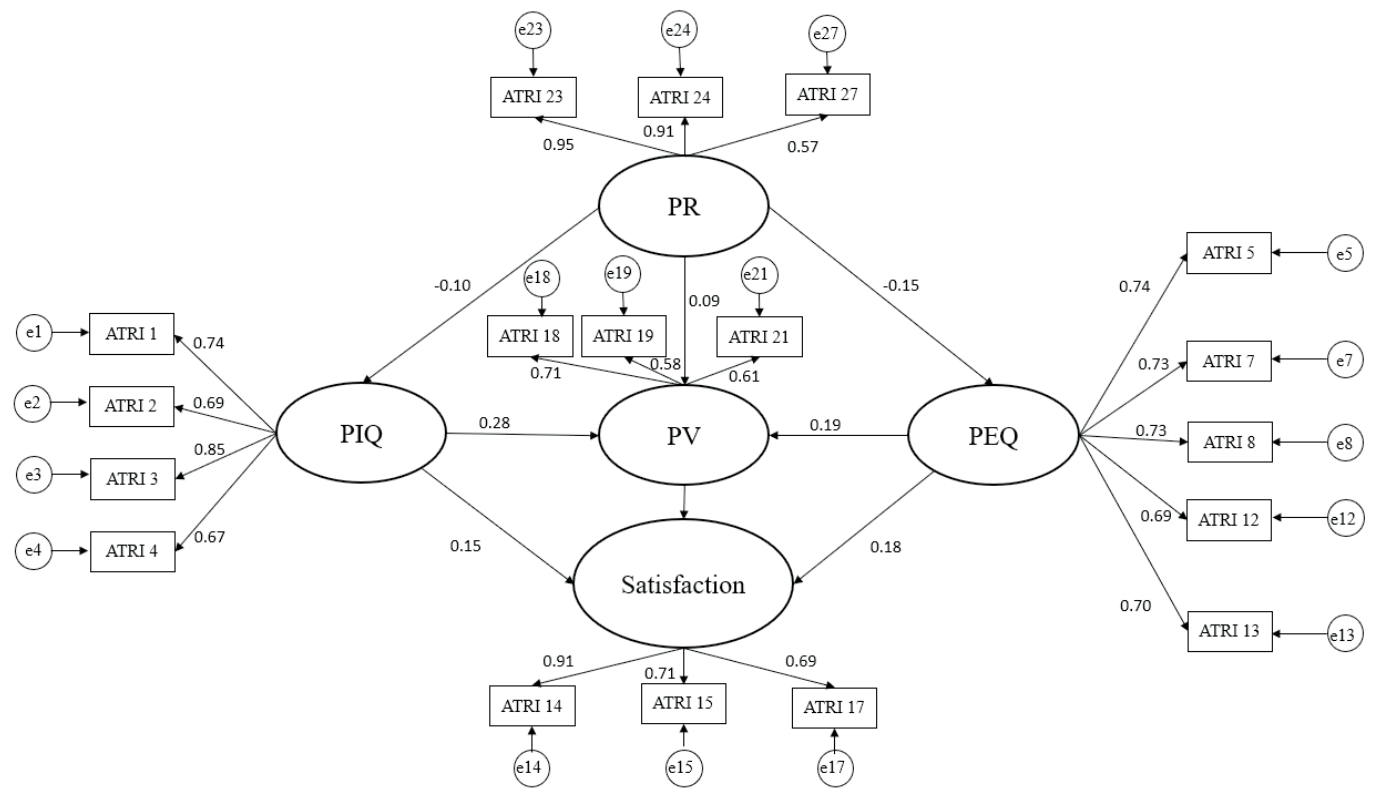

Table 4. Cronbach's $\alpha$ and composite reliability and convergent validity of the construct

\begin{tabular}{lccc}
\hline Proposed construct & Cronbach's $\alpha$ & Composite reliability & Average variance extracted \\
\hline Perceived intrinsic quality & 0.800 & 0.789 & 0.558 \\
Perceived extrinsic quality & 0.817 & 0.811 & 0.518 \\
Satisfaction & 0.809 & 0.794 & 0.575 \\
Perceived value & 0.760 & 0.765 & 0.535 \\
Risk perceived & 0.845 & 0.862 & 0.684
\end{tabular}

time, the composite reliability determined that the constructs are reliable for measurement as a whole. Likewise, the convergent validity of the construct indicated that the attributes of the latent variables share more than $50 \%$ of the explained variance.

The goodness of fit of the model fulfills the stipulation in the literature: absolute measures of fit RMSEA $=0.00$ and incremental measures of fit $\mathrm{CFI}=0.967$.

With respect to the contrasting hypothesis (Table $5)$, it was determined with $95 \%$ confidence $(p<0.05)$ that only perceived risk is related to the perceived extrinsic quality of the product, and there was no relation with the perceived intrinsic quality.
This allows us to reject hypothesis 1 and accept hypothesis 2. In this respect, Midmore et al. (2011) conclude in their study on organic products that more habitual consumers directly related quality to lower risk and greater safety when acquiring products; in contrast, this relation does not exist in occasional consumers of organic products. In this area and on the basis of the attributes identified, the French consumer will not prefer avocados with artificial processing and preservation, reducing their perceived quality and paying less than for a product with organic processing.

Ness et al. (2010) determined in five of six European countries that there is a relation between the risks considered by the consumer and the value they perceive, which contradicts the results obtained 
Table 5. Hypothesis testing

\begin{tabular}{llcc}
\hline Hypothesis & & Critical ratio & Contrast \\
\hline Risk perceived & $\rightarrow$ Perceived intrinsic quality & -1.639 & Reject \\
Risk perceived & $\rightarrow$ Perceived extrinsic quality & -2.412 & Accept \\
Risk perceived & $\rightarrow$ Perceived value & 1.746 & Reject \\
Perceived extrinsic quality & $\rightarrow$ Perceived value & 3.161 & Accept \\
Perceived intrinsic quality & $\rightarrow$ Perceived value & 4.340 & Accept \\
Perceived value & $\rightarrow$ Satisfaction & 5.059 & Accept \\
Perceived intrinsic quality & $\rightarrow$ Satisfaction & 2.389 & Accept \\
Perceived extrinsic quality & $\rightarrow$ Satisfaction & 2.880 & Accept
\end{tabular}

in this study, where the relation in French avocado consumers was not demonstrated statistically; hence, hypothesis 3 is rejected.

Perceived extrinsic and intrinsic quality and perceived value present a direct and significant relation to each other, so hypotheses 4 and 5 are accepted. Although Konuk (2018) identified a similar relation in his studies on organic foods, there has been no evidence of works on statistical models in Europe about fruits and vegetables that can distinguish relations that differentiate between perceived extrinsic and intrinsic quality and perceived value.

Finally, hypotheses 6, 7 and 8 are accepted. The results indicate that perceived value, perceived extrinsic and intrinsic quality directly and significantly influence French consumer satisfaction in the preference for Chilean avocados, explaining 19.97\% of the model. The results show through the critical ratio that perceived value presents a greater degree of relation to satisfaction than perceived quality. Other food studies in France, such as that by Ness et al. (2010), only found a direct and significant relation between perceived value and satisfaction, with perceived quality of the foods not being a precedent. On the other hand, perceived extrinsic quality presents a greater degree of relation to satisfaction than does perceived intrinsic quality, which shows that consumers prioritize the product's external attributes, such as price, product availability in the supermarket, price discounts and availability in bulk.
In conclusion, this study supports the statistical reliability that perceived extrinsic and intrinsic quality and perceived value significantly and positively influence satisfaction. French consumers base their satisfaction on both qualities; in other words, they consider not only the inherent attributes of the fruit, such as size, color and texture, but also other attributes external to the product that give it greater value. In addition, it was found that perceived value is the variable with the strongest influence on consumer satisfaction, which is why Chilean exporters should focus their efforts on the nutritional status of avocados and pricing policies. The analyzed data could give way to competitive advantage strategies of exporters over other supplying countries, such as Peru and Spain, their main zonal and seasonal competitors (Rodríguez et al., 2018). The strategies must also take into account other external factors, such as major droughts that affect countries across the board, especially European ones (Kourgialas and Dokou, 2021). The low explanatory value of the satisfaction of French consumers in the preference for Chilean avocado reveals that new variables must be incorporated to obtain a better explanation of the model. These may be purchase intent, consumer confidence, cocreation of value, corporate social responsibility, and consumer loyalty, which could be integrated into the model. On the other hand, it is necessary to generate contrasts of perception and satisfaction by incorporating other markets offering avocados such as Peru, Mexico and Spain. 


\section{Resumen}

R. Cabana Villca, M.I. Ortega Marín, A.A. Gutiérrez Rojas, M.I. Aguilera Zambra, y A.F. Chiang Guzmán. 2021. Factores que influyen en la satisfacción del consumidor francés en la preferencia por paltas chilenas (Persea Americana Mill). Int. J. Agric. Nat. Resour. 45-56. La mayor parte de las paltas consumidas en Francia provienen principalmente de Perú y Chile. Los proveedores de Francia varían en función de la temporada, sin embargo, Chile se mantiene como el principal proveedor durante la temporada de invierno. El objetivo de esta investigación es analizar las variables claves que influyen en la satisfacción de los consumidores franceses al preferir paltas de origen chileno. Esto se fundamenta mediante un análisis multivariado de carácter exploratorio, el cual se realizó sobre un modelo causal compuesto por los constructos endógenos: calidad percibida extrínseca e intrínseca, riesgo percibido y valor percibido. La muestra consta de 346 consumidores franceses de paltas chilenas en supermercados de la región Ródano-Alpes. Entre los principales resultados se demostró que el riesgo percibido por los consumidores franceses sólo puede estar relacionado a la calidad percibida extrínseca del producto. Por otra parte, tanto calidad percibida intrínseca como extrínseca están directamente relacionadas al valor percibido. Finalmente se concluye, que la satisfacción del consumidor francés al preferir paltas de origen chileno puede ser explicado por las variables: Calidad percibida intrínseca, calidad percibida extrínseca y valor percibido.

Palabras Clave: Calidad percibida, Francia, modelos de ecuaciones estructurales, palta, riesgo percibido, valor percibido.

\section{References}

Baselice, A., Colantuoni, F., Lass, D., Nardone, G., \& Stasi, A. (2017). Trends in EU consumers' attitude towards fresh-cut fruit and vegetables. Food Quality and Preference, 59, 87-96.

Chiang, A., Schnettler, B., Mora, M., \& Aguilera, M. (2018). Perceived quality of and satisfaction from sweet cherries (Prunus avium L.) in China: Confirming relationships through structural equation. International Journal of Agriculture Resources, 45(3), 210-219.

Eygue, M., Richard-Forget, F., Cappelier, J.M., Pinson-Gadais, L., \& Membré, J.M. (2020). Development of a risk-ranking framework to evaluate simultaneously biological and chemical hazards related to food safety: Application to emerging dietary practices in France. Food Control, 115, 107279.
Espejel, J., \& Fandos, C. (2009). Wine marketing strategies in Spain. A structural equation approach to consumer response to protected designations of origin (PDOs). International Journal of Wine Business Research, 21, 267-288.

García, J., Gálvez, P., Fernández, J., Vélez, L., Pitts, B., \& Bernal, A. (2017). The effects of service convenience and perceived quality on perceived value, satisfaction and loyalty in low-cost fitness centers. Sport Management Review, 21, 250-262.

Gazan, R., Béchaux, C., Crépet, A., Sirot, V., Drouillet-Pinard, P., Dubuisson, C., \& Havard, S. (2016). Dietary patterns in the French adult population: a study from the second French national cross-sectional dietary survey (INCA2) (2006-2007). British Journal of Nutrition, 116(2), 300-315.

Han, H., \& Hyun, S. (2017). Impact of hotel-restaurant image and quality of physical-environment, 
service, and food on satisfaction and intention. International Journal of Hospitality Management, 63, 82-92.

Hurgobin, Y., Le Floch, V., \& Lemercier, C. (2020). Effect of multiple extrinsic cues on consumers' willingness to buy apples: A scenario-based study. Food Quality and Preference, 81, 103860.

Iglesias, I., Echeverria, G., \& Soria, Y. (2008). Differences in fruit colour development, anthocyanin content, fruit quality and consumer acceptability of eight 'Gala'apple strains. Scientia Horticulturae, 119(1), 32-40.

Insch, A., \& Cuthbert, R. (2018). Why country of origin still matters in food retailing: Implications for promotion management research. Journal of Promotion Management, 24(3), 363-375.

ITC. (2020a). List of supplying markets for a product imported by Francia. Retrieved from: https:// www.trademap.org/Country_SelProductCountry_TS.aspx?nvpm $=3 \% 7 \mathrm{c} 251 \% 7 \mathrm{c} \% 7 \mathrm{c} \% 7 \mathrm{c} \% 7 \mathrm{c}$ $080440 \% 7 \mathrm{c} \% 7 \mathrm{c} \% 7 \mathrm{c} 6 \% 7 \mathrm{c} 1 \% 7 \mathrm{c} 1 \% 7 \mathrm{c} 1 \% 7 \mathrm{c} 2 \% 7$ c1\%7c2\%7c2\%7c1\%7c1.

ITC. (2020b). List of importing markets for a product exported by Chile. Retrieved from: https://www. trademap.org/Country_SelProductCountry_TS.a spx?nvpm=1\%7c152\%7c\%7c\%7c\%7c080440\% $7 \mathrm{c} \% 7 \mathrm{c} \% 7 \mathrm{c} 6 \% 7 \mathrm{c} 1 \% 7 \mathrm{c} 1 \% 7 \mathrm{c} 2 \% 7 \mathrm{c} 2 \% 7 \mathrm{c} 1 \% 7 \mathrm{c} 2$ $\% 7 \mathrm{c} 2 \% 7 \mathrm{c} 1 \% 7 \mathrm{c} 1$.

Kendall, H., Clark, B., Rhymer, C., Kuznesof, S., Hajslova, J., Tomaniova, M., Brereton, P., \& Frewer, L. (2019). A systematic review of consumer perceptions of food fraud and authenticity: A European perspective. Trends in Food Science \& Technology, 94, 79-90.

Konuk, F. (2018). The role of store image, perceived quality, trust and perceived value in predicting consumers' purchase intentions towards organic private label food. Journal of Retailing and Consumer Services, 43, 304-310.

Kourgialas, N.N., \& Dokou, Z. (2021). Water management and salinity adaptation approaches of Avocado trees: A review for hot-summer Mediterranean climate. Agricultural Water Management, 252, 106923.

Marakanon, L. \& Panjakajornsak, V. (2017). Perceived quality, perceived risk and customer trust affecting customer loyalty of environmentally friendly electronics products. Kasetsart Journal of Social Sciences, 38(1), 24-30.

Lombart, C., \& Louis, D. (2014). A study of the impact of Corporate Social Responsibility and price image on retailer personality and consumers' reactions (satisfaction, trust and loyalty to the retailer). Journal of retailing and consumer services, 21(4), 630-642.

Marti, L., Puertas, R., \& García-Álvarez-Coque, J.M. (2021). The effects on European importers' food safety controls in the time of COVID-19. Food Control, 125, 107952.

Mertens, E., Kuijsten, A., Dofková, M., Mistura, M., D’Addezio, L., Turrini, A., Dubuisson, C., Favret, S., Havard, S., Trolle, E., Van't, P., \& Geleijnse, J. (2018). Geographic and socioeconomic diversity of food and nutrient intakes: A comparison of four European countries. European journal of nutrition, 58(4), 1475-1493.

Midmore, P., Francois, M., \& Ness, M. (2011). Trans-European comparison of motivations and attitudes of occasional consumers of organic products. NJAS-Wageningen Journal of Life Sciences, 58(3-4), 73-78.

Mora, M., Espinoza, J., Schnettler, B., Echeverría, G., Predieri, S., \& Infante, R. (2011). Perceived quality in fresh peaches: an approach through structural equation modeling. International Journal of Agriculture Resources, 38, 179-190.

Moreno-Ortega, G., Pliego, C., Sarmiento, D., Barceló, A., \& Martínez-Ferri, E. (2019). Yield and fruit quality of avocado trees under different regimes of water supply in the subtropical coast of Spain. Agricultural Water Management, 221, 192-201.

Ness, M.R., Ness, M.B., Oughton, E., Ritson, C., \& Ruto, E. (2010). Modelling consumer behavioural intentions towards food with implications for marketing quality low-input and organic food. Food Quality and Preference, 21, 100-111.

PROCHILE. (2018). Avocado Market Study in France. Santiago, Chile. Retrieved from: https://www.prochile.gob.cl/wp-content/uploads/2019/04/pmp_palta_francia_2018.pdf.

Perrin, C., Battisti, C., Chambefort, A., Digaud, O., Duplessis, B., Volatier, J., Gauvreau-Beziat, J., 
\& Menard, C. (2017). Range of processed foods available in France and nutrition labelling according to the type of brand. Journal of Food Composition and Analysis, 64, 156-162.

Plessz, M., Guéguen, A., Goldberg, M., Czernichow, S., \& Zins, M. (2015). Ageing, retirement and changes in vegetable consumption in France: findings from the prospective GAZEL cohort. British Journal of Nutrition, 114(6), 979-987.

Schnettler, B., Hueche, C., Andrades, J., Ares, G., Miranda, H, Orellana, L., \& Grunert, K. (2020). How is satisfaction with food-related life conceptualized? A comparison between parents and their adolescent children in dual-headed households. Food Quality and Preference, 86, 104021.
Shaharudin, M., Pani, J., Mansor, S., Elias, S., \& Sadek, D. (2010). Purchase intention of organic food in Kedah, Malaysia; A religious overview. International Journal of Marketing Studies, 2(1), 96.

Yeung, R., Yee, W., \& Morris, J. (2010). The effects of risk-reducing strategies on consumer perceived risk and on purchase likelihood A modelling approach. British Food Journal, †112(2-3), 306-322.

Yu, J., Lee, H., Ha, I., \& Zo, H. (2017). User acceptance of media tablets: An empirical examination of perceived value. Telematics and Informatics. 34(4), 206-223.

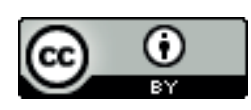

This work is licensed under a Creative Commons Attribution 4.0 International License. 